\title{
Personality and Leadership as Antecedents of Organizational Citizenship Behaviour: A Study of Mining Company in Goa
}

\author{
Sonam J Gondlekar*
}

\section{Abstract}

This study investigates the relationship between personality factors, leadership and organizational citizenship behaviour (OCB), predict changes in OCB by personality and leadership, and analyze the influence of demographic variables (organizational tenure, educational qualifications, age, designation, gender and job status) on OCB, personality, leadership and their dimensions. The sample consisted of 203 employees from three units of Sesa Goa Ltd., a leading mining company in Goa. Three reliable and valid tools were employed for the assessment-Organizational Citizenship Behaviour, NEO Five Factor Inventory and Leadership Effectiveness scale. Results of correlation analysis indicated positive correlation between leadership (all dimensions) and OCB. Of five personality factors, extraversion, agreeableness and conscientiousness showed positive correlation while neuroticism was found to be negatively correlated with OCB. Furthermore, result of regression analysis unveiled that $18 \%$ variance in OCB is contributed by leadership and $11 \%$ by personality. Unit wise differences were also evident in OCB. An incidental analysis using One Way ANOVA and $t$ test revealed significant influence of organizational tenure and educational level on OCB. No significant difference was noticed on leadership and any of its dimensions. This study provides guidelines to aid managers better understand how to enhance OCB.

Soft Skill Trainer \& HR Consultant, Goa, India; sonam.gondlekar@rediffmail.com 
Keywords: Organizational citizenship behaviour, Personality, Leadership, Mining

\section{Introduction}

Cooking a delicious meal requires certain ingredients such as oil and salt, however when some extra seasoning happens, the meal will become tastier. This metaphor introduces the concept 'Organizational Citizenship Behaviour' (OCB). Oil and salt representing the tasks employees have to perform and seasoning symbolizes OCB: "Individual behaviour at work that is discretionary, not directly or explicitly recognized by the formal reward system and in the aggregate promotes the efficient and effective functioning of the organization" (Organ, 1988). In effective organizations, employees often go beyond formal job roles, performing tasks voluntarily with no expectation of recognition or reward. These selfless acts are neither prescribed nor required, yet they contribute to the functioning of the organization.

Over last decade there has been an increasing interest among researchers to investigate the contextual and dispositional factors responsible for eliciting organizational citizenship behaviour (OCB). This widespread interest in OCB primarily stems from the fact that OCB leads to improved organizational effectiveness (Podsakoff, Ahearne, MacKenzie, 1997; Podsakoff \& MacKenzie, 1994).

\section{Organ's Model of Organizational Citizenship Behaviour:}

The five dimensions outlined in this model are altruism, conscientiousness, sportsmanship, courtesy and civic virtue.

Conscientiousness is defined as upholding high level work awareness which includes voluntary behaviour that goes beyond the lowest expected role definition and performance of workmen is more than expected lowest level. Courtesy attitude covers all behaviours for helping others in avoiding problems to occur. Sportsmanship is defined as refraining from actions which may lead to unfavourable tension at the workplace and maintaining synergistic atmosphere within the organization against any adverse incidents (Organ, 1988, 1990; Podsakoff and et al., 2000). Helping 
behaviour/Altruism includes all types of voluntary actions of workmen displayed to help the fellow workmen in performing their work and overcoming problems within the organization (Organ, 1988; 1990; Podsakoff and et al., 2000). Civic Virtue means high level interest in and high level loyalty to the organization.

\section{Leadership}

Pfiffner (2002) has described leadership as "the art of coordinating and monitoring individuals and groups to achieve desired ends". While distinguishing it from command, he said that ideally leadership involves more of persuasion than command so that the authority is accepted naturally. However he felt that the two cannot be separated.

Leadership effectiveness involves a group process with the leader as the main directive element. As Chester (1962) put it several decades ago, effectiveness is "the accomplishment of the recognized objectives of the cooperative action". It depends initially on influence, but beyond that there are questions of value, such as how things are done and to achieve what ends.

\section{Aspects of Leadership Effectiveness}

Following an exhaustive review of literature, several experts in the field have put forth Six (6) major areas which covers almost all the aspects of leadership effectiveness. A brief description of each area is as follows:

Interpersonal Relations: leadership effectiveness depends upon followers perceiving and responding to the leader's display of competence, fairness and identification.

Intellectual Operations: The most effective leaders appear to exhibit a greater degree of versatility and flexibility that enables them to adapt their behaviour to the changing and contradictory demands made on them.

Behavioural and Emotional Stability: Leaders regularity and practicability of behaviour is important in smoothing ongoing interaction.

Ethical and Moral Strength: The leader who has ethical and moral commitment/strength is fully committed to the goals of the 
organization and his role in accomplishing these goals. A leader who values his organization's goals and takes great pride in fulfilling his organizational role will be example of his moral strength.

Adequacy of Communications: Effective leadership uses communication to get people committed to a joint activity with a common plan. Barnard (1962) said, "Infusing a belief in a common purpose is an essential executive function."

Operation as a Citizen: An effective leader should be a friendly liaison officer between the organization and the community.

\section{Personality}

'Personality is that pattern of characteristic thoughts, feelings, and behaviours that distinguishes one person from another and that persists over time and situation (Phares, 1991). It is the sum of biologically based and learnt behaviour which forms the person's unique responses to environmental stimuli (Ryckman, 1982). (Costa \& McCrae, 1989; Funder, 2001), Personality traits refer to enduring patterns of thought, emotion, and behaviour that are not likely to change over time and explain people's behaviour across different situations.

\section{Big Five Personality Dimensions}

Neuroticism is a measure of affect and emotional control. Extraversion-introversion dimension contrasts an outgoing character with a withdrawn nature. Openness to experience is a measure of depth, breadth and variability in a person's imagination and urge for experiences. Agreeableness scale is linked to altruism, nurturance, caring and emotional support versus competitiveness, hostility, indifference, self-centeredness, spitefulness and jealousy (Howard \& Howard, 1995). Conscientiousness is a measure of goal-directed behaviour and amount of control over impulses.

\section{Significance of the Study}

This study is conducted to enhance our understanding of organizational citizenship behaviour as identified in the organizational behaviour literature. This study will enhance our 
understanding of the antecedents of organizational citizenship behaviour. It is also designed to provide mining industry managers with insights into the employee's personality, effectiveness of the leaders and their degree of organizational citizenship behaviour. The present study will also help managers better understand how to improve employee's organizational citizenship behaviour, which in turn will help improve organizational productivity, profits and make the organization more effective.

\section{Literature Review}

Asgari, Silong, Ahmad, \& Samah, (2008) conducted a study, which aimed to assess the impact of six dimensions of transformational leadership behaviours - contribution and affect - on citizenship behaviour and to test the mediating impact of LMX on the transformational leadership behaviours and citizenship relationship. The subjects of this study were full-time employees with their managers working in the educational organization in Iran. Data were collected on a structured questionnaire containing standard scales of transformational leadership behaviors, LMX, and organizational citizenship behaviors. Results indicated that dimensions of transformational leadership behaviours are more likely to predict citizenship behaviour than the affect dimension of LMX. Further, LMX is not mediating the relationship of transformational leadership behaviors with citizenship behavior.

Kumar, Bakhshi, \& Rani, (2009) explored the linkages between personality and organizational citizenship behavior (OCB) using a field sample. Big-Five personality model was used to explore the relationship between personality and OCB. The participants in the study were 187 doctors working in a medical college in north India. Four of the 'big five' factors except Neuroticism were positively correlated with OCB. Hierarchical regression analysis on data after controlling for demographic variables indicated that, Conscientiousness, Extraversion, Agreeableness and Neuroticism were valid predictors for OCB. However, Openness to experience showed no significant relationship with overall measure of OCB. 


\section{Research Methodology}

\section{Problem}

The present investigation is undertaken to study the relationships between Leadership, Personality and Organizational Citizenship Behaviour in Sesa Goa Limited, a leading mining Company in Goa.

\section{Objectives of the Study}

1. To examine the effect of Leadership \& Personality on Organizational Citizenship Behaviour.

2. To study the effect of organizational tenure, education, age, designation, gender and job status, on Leadership and Organizational Citizenship Behaviour.

\section{Variables Investigated}

Organizational citizenship behaviour, Leadership, Personality, Organizational Tenure (0-4, 5-9, 10-14, 15-19, 20-24, 25 yrs \& above), Education (SSC, HSSC, Graduation, Post Graduation), Age (20-29, 30-39, 40-49, 50yrs \& above), Designation (Higher, Middle, Lower), Gender (Males \& Females), Job status (Temporary \& Permanent)

\section{Sample}

The sample comprised of 203 higher, middle and lower level employees belonging to different age groups (mentioned above). Representative sample was chosen from three units that is (Codli, Sonshi, Amona). Selected sample consisted of both trainees and permanent employees, employees with different job tenures and varied educational qualifications. The sample was chosen randomly.

\section{Tools for Data Collection}

Three scales were used in the study to measure the constructs of interest.

1. Organizational Citizenship Behaviour: This Scale was developed by Bakhshi \& Kumar. This scale consists of 30 items, which are classified under 5 dimensions, namely, Conscientiousness, Courtesy, Sportsmanship, Helping Co- 
worker, Civic Virtue. The reliability of the whole scale was found to be 0.82 .

2. Leadership Effectiveness scale (A Measure of Leader's Characteristics): This scale was developed by Taj and consists of 79 items. Items cover six aspects of leadership effectiveness, namely; interpersonal relations, intellectual operations, behavioural \& emotional stability, ethical \& moral strength, adequacy of communication \& operations as a citizen. The test-retest reliability coefficient was found to be 0.60 with a time gap of 2 weeks and split - half reliability coefficients by odd and even and first half and second half method were found to be 0.64 and 0.67 respectively.

3. NEO Five-Factor Inventory: NEO - FFI developed by Costa \& McCrae is a 60 item version of Form $S$ of the NEO PI - R that provides a brief, comprehensive measure of the five domains of personality. These five domains are Neuroticism (N), Extroversion (E), Openness (O), Agreeableness (A) and Conscientiousness (C). Reliability is $.92, .90, .91, .77$ and .87 for $\mathrm{N}, \mathrm{E}, \mathrm{O}, \mathrm{A}$, and $\mathrm{C}$ domains, respectively. With regard to validity, the convergent correlations range from .56 to .62; none of the divergent correlations exceeds 20 .

\section{Tools for Statistical Analysis}

In order to test the hypotheses and to facilitate the interpretation of results, data was analyzed by applying various statistical techniques. Both descriptive and inferential methods were used to analyze the data that is, mean, standard deviation, Pearson Product Moment Correlation, $\mathrm{t}$ test, ANOVA \& regression.

\section{Result and Discussion}

Ha1: There is a significant positive correlation between Leadership and Organizational Citizenship Behaviour.

Leadership has a positive influence on organizational citizenship behaviour, as hypothesized. Using Pearson's Product Moment 
Correlation, correlation coefficient was computed, which was found to be .42 , thereby proving significant at $1 \%$ level of significance. The same is depicted in Table 1.1. Correlation coefficient signifies a positive correlation, indicating that, if leader is perceived as effective, greater is the probability that employees will engage in organizational citizenship behaviours. In other words, if employees perceive that leader displays fairness, competence, exhibit a greater degree of versatility and flexibility, shows regularity and practicability of behaviour, holds ethical and moral commitment, is fully committed to the goals of the organization and his role in accomplishing these goals, uses communication to get people committed to a joint activity, and finally is a friendly liaison officer between the organization and the community, only then, employees will go beyond their explicit role requirements and engage in activities like helping others with their jobs, supporting the organization or volunteering for additional work or responsibility, which are pigeonholed as "Organizational Citizenship Behaviour".

Table 1.1: Relationship between the dimensions of Leadership and Organizational Citizenship Behaviour

\begin{tabular}{|l|c|}
\hline \multicolumn{2}{|c|}{ Leadership $(\mathrm{N}=203)$} \\
\hline Coefficient of Correlation & $\begin{array}{c}\text { Organizational Citizenship } \\
\text { Behaviour }\end{array}$ \\
\hline Interpersonal relations & $.35^{* *}$ \\
\hline Intellectual Operations & $.39^{* *}$ \\
\hline Behavioural \& Emotional Stability & $.33^{* *}$ \\
\hline Ethical \& Moral Strength & $.36^{* *}$ \\
\hline Adequacy of Communication & $.42^{* *}$ \\
\hline Operations as a citizen & $.40^{* *}$ \\
\hline Leadership (Total) & $.42^{* *}$ \\
\hline
\end{tabular}

**Significant at $1 \%$ level

The positive relationship between leadership and organizational citizenship behaviour is consistent with the findings of Noormala \& Syed (2009); Perumalu \& Ibrahim, Ching P, C., Chiung, Ching-Yi Lee, Deluga \& Ronald J. (1994) who also found a positive correlation between leadership and organizational citizenship behaviour. 
A further analysis hooked on computing the correlation between dimensions of leadership and organizational citizenship behaviour provided an interesting insight. Results of dimension wise analysis revealed that all six dimensions of leadership correlated positively with organizational citizenship behaviour. Correlation coefficients derived from correlation between each of the six dimensions of leadership; namely, interpersonal relations (.35), intellectual operations (.39), behavioural and emotional stability (.33), ethical and moral strength (.36), adequacy of communication (.42), operations as a citizen (.40) and organizational citizenship behaviour were found to be significant at $1 \%$ level of significance. This insinuates that employees will engage in organizational citizenship behaviours only if they perceive their leader as effective. Thus, a leader can influence an employee's motivation, ability or opportunity to engage in organizational citizenship behaviour through his own behaviour.

However, correlation analysis between leadership and dimensions of organizational citizenship behaviour revealed some captivating findings. Leadership was discovered to be positively correlated with all six dimensions of OCB namely, conscientiousness (.30), courtesy (.19) sportsmanship (.31), helping co worker (.34) and civic virtue (.28); correlation coefficients for which were found significant at $1 \%$ level of significance. Thus these findings attest that there is a significant association between all the dimensions of leadership and overall OCB as well as all the dimensions of OCB and leadership. Thus, leadership seems to have a strong relationship with organizational citizenship behaviour.

\section{Ha2: There is a significant positive correlation between Personality and Organizational Citizenship Behaviour.}

Using Pearson's Product Moment Correlation method, correlation between personality and organizational citizenship behaviour was computed. As, hypothesized, there is a positive correlation between personality and organizational citizenship behaviour. Correlation coefficient was found to be .33 , which is significant at $1 \%$ level of significance. 
To discover more about this relationship, dimension wise analysis was done to find out whether all five dimensions of personality correlate with organizational citizenship behaviour.

Firstly, negative correlation was noticed between Neuroticism and organizational citizenship behaviour. Correlation coefficient was computed as -.35 , which is significant at $1 \%$ level of significance. Thus, results reveal that, employees who score high on neuroticism will display less organizational citizenship behaviour, whereas employees who score low on neuroticism will display high OCB. Low scorers on neuroticism are characterized as being emotionally stable, are usually calm and relaxed under stressful or difficult situations, often feel secure and are self satisfied. High scorers, on the other hand are just contradictory to this. In sum, as employees who score low on neuroticism are characterized by these traits, they display more OCB than their counterparts. Consistent with previous research findings (Singh and Singh; Kumar, Bakhshi \& Rani, 2009), results of this study also revealed that emotionally stable employees will display more organizational citizenship behaviour, as opposed to their counterparts.

Table 2.1: Relationship between the dimensions of Personality and Organizational Citizenship Behaviour

\begin{tabular}{|l|c|}
\hline \multicolumn{2}{|c|}{ Personality $(\mathrm{N}=203)$} \\
\hline Coefficient of Correlation & $\begin{array}{c}\text { Organizational Citizenship } \\
\text { Behaviour }\end{array}$ \\
\hline Neuroticism & $-.35^{* *}$ \\
\hline Extraversion & $.29^{* *}$ \\
\hline Openness to experience & -.005 \\
\hline Agreeableness & $.16^{*}$ \\
\hline Conscientiousness & $.56^{* *}$ \\
\hline Personality (Total) & $.33^{* *}$ \\
\hline
\end{tabular}

**Significant at $1 \%$ level

*Significant at $5 \%$ level

Secondly, as hypothesized, there is a positive correlation between extraversion and organizational citizenship behaviour. Correlation coefficient was derived as .29 which proved to be significant at $1 \%$ level of significance. Findings denote that, highly extraverted employees will display more Organizational citizenship behaviour 
and vice versa. One possible explanation for this finding is employees who are high in extraversion are generally sociable, assertive, active, bold, energetic, adventuresome and expressive. Thus, those who are highly extraverted display more flexible behaviours, which make them more likely to show organizational citizenship behaviour. The result of this study supports previous research on the relationship between extraversion and organizational citizenship behaviour. (Hogan \& Holland, 2003; Hough, 1992; Hurtz \& Donovan, 2000; Organ \& Ryan, 1995; Kumar, Bakhshi \& Rani, 2009; Singh, \& Singh, 2009.

Thirdly, contrary to what was hypothesized, no significant correlation was observed between openness to experience and organizational citizenship behaviour. Correlation coefficient was computed as -.005, which connotes a weak negative correlation. Open individuals display a preference for variety; enjoy grasping new ideas, and have an intrinsic interest in and appreciation for novelty. Thus, study had hypothesized that employees high on openness to experience are more likely to show OCB. But derived results are contrary to the hypothesis. Findings however support previous studies which also reported weak relationship between openness to experience and organizational citizenship behaviour (Barrick et al., 2001; Hogan \& Holland, 2003; Hough, 1992; Hurtz \& Donovan, 2000; Mount et al., 1998; Organ \& Ryan, 1995).

Fourthly, positive correlation was observed between agreeableness and organizational citizenship behaviour. Correlation coefficient was found to be .16 , which is significant at $5 \%$ level of significance. This implies that, employees who score high on agreeableness will show more organizational citizenship behaviour, than employees who score low on agreeableness. One possible explanation for this is that, employees who score high on agreeableness tend to be courteous, flexible, trusting, good natured, cooperative, forgiving, soft hearted, and tolerant. Even in work contexts, agreeable employees show higher levels of interpersonal competence and collaborate effectively when joint action is needed. All these are individual traits that would result in higher OCB performance. Thus, it was expected that persons high on agreeableness are more likely to perform OCB and same was reflected in the findings. Similar findings were reported in studies of (Elanain, 2007; Kumar 
K, Bakhshi \& Rani, 2009; Singh \& Singh, 2009; King, George \& Hebl,2005) who also found significant relationship between agreeableness and organizational citizenship behaviour.

Lastly, results of correlation analysis revealed correlation coefficient of .56 between conscientiousness and organizational citizenship behaviour, and proved to be significant at $1 \%$ level of significance. This signifies a positive correlation, which means that highly conscientious employees will display more organizational citizenship behaviour and vice versa. This is probably because; employees who are high in conscientiousness generally perform better at work than those who are low in conscientiousness. Conscientious employees can perform their part of the work with a minimum of oversight. They are predisposed to take initiative in solving problems and are more methodical and thorough in their work. These are the traits that would obviously result in higher OCB performance. Also, the result of this study supports previous studies (Bukhari, 2008; Konovsky \& Dennis,1996; King, George \& Hebl, 2005) which also reported significant positive correlation between conscientiousness and organizational citizenship behaviour.

\section{Ha 3: Leadership is a predictor of Organizational Citizenship Behaviour.}

Linear regression was performed to examine the causal link between leadership and organizational citizenship behaviour.

Results obtained from linear regression revealed that Leadership is significantly positively associated with Organizational citizenship behaviour. As can be seen from the Table 3.1, standardized beta coefficient is $.42(\mathrm{P}=.000)$ which means that, a one standard deviation increase in leadership would yield a .42 standard deviation increase in the predicted organizational citizenship behaviour. Thus, this beta coefficient attests that the connection between leadership and organizational citizenship behaviour is significant. The result further specify that the direction of the association is positive which means that employees will engage in organizational citizenship behaviour only if they perceive their leader as effective. For leader to be perceived as effective, he should have good interpersonal relations with his followers, should be 
behaviourally and emotionally stable, practical, unbiased and should communicate frequently with followers. However, if employees happen to perceive leader as ineffective, than chances are higher that employees will not engage in organizational citizenship behaviour.

Table 3.1: Regression Analysis showing Organizational Citizenship Behaviour as Dependent Variable and Leadership as Predictor variable

\begin{tabular}{|l|c|c|c|c|c|c|}
\hline $\begin{array}{l}\text { Regression } \\
\text { Model }\end{array}$ & $\mathbf{R}$ & $\begin{array}{c}\text { R } \\
\text { Square }\end{array}$ & $\begin{array}{c}\text { Adjusted } \\
\text { R Square }\end{array}$ & F-value & Df & $\begin{array}{c}\text { Beta } \\
\text { Value }\end{array}$ \\
\hline $\begin{array}{l}\text { Dependent } \\
\text { Variable: }\end{array}$ & & & & & & \\
$\begin{array}{l}\text { Organizational } \\
\text { Citizenship } \\
\text { Behaviour }\end{array}$ & 0.42 & 0.18 & 0.17 & $43.523^{* *}$ & $\begin{array}{c}1, \\
201\end{array}$ & 0.42 \\
\hline
\end{tabular}

** Significant at $1 \%$ level

$\mathrm{R}$ square explains the strength of the relationship between predictor and dependent variable. In this case, it is leadership and organizational citizenship behaviour. The $\mathrm{R}$ square was found to be .18 , which suggests that approximately $18 \%$ of the variance of organizational citizenship behaviour is accounted for by the predictor that is leadership. As can be seen in the Table 3.1, F value was computed as $43.523(\mathrm{P}=.000)$ and its significance value is less than 0.01 , which means that variation explained by the predictor, that is, leadership is not due to chance. It also connotes the significance of the model in predicting organizational citizenship behaviour. So, significant $F$ value implies that; leadership is a strong predictor of organizational citizenship behaviour.

The results of this study are consistent with the findings of study of Asgari, Silong, Ahmad \& Sama (2008), on the relationship between transformational leadership and organizational citizenship behaviours. The study reported leadership as a valid predictor of organizational citizenship behaviour.

Further, linear regression was executed to model the value of organizational citizenship behaviour, based on its relationship to a set of predictors that is dimensions of leadership. It was evident 
through results of linear regression that leadership predicts organizational citizenship behaviour. So, the aim was to investigate whether all six dimensions of leadership also predict organizational citizenship behaviour.

Results revealed that out of six, only one dimension of leadership proved as significant predictor of organizational citizenship behaviour.

The results of this study show that association between Operations as a citizen and organizational citizenship behaviour is significant with beta coefficient $=.25(\mathrm{P}=.030)$. The direction of association is positive, which indicates that; for employees to engage in organizational citizenship behaviour, leader should act as a friendly liaison officer between the organization and the community. He should be adept in fostering good public relations, securing community participation for improving and developing his institution, making institution conscious of the need to serve the community better.

Surprisingly, results of this study shows that association between Interpersonal relations and organizational citizenship behaviour is not significant with beta coefficient $=-.31(\mathrm{P}=.052)$. In fact, direction of association is also negative, which means that better interpersonal relations between leader and followers leads to lower organizational citizenship behaviour. Even adequacy of communication, intellectual operations, Behavioural and emotional stability, ethical and moral strength did not prove as a significant predictor of organizational citizenship behaviour. Beta coefficient were found to be $($ Beta $=.30 ; \mathrm{P}=.068)$, $($ Beta $=.18 ; \mathrm{P}=.147)$, $($ Beta $=$ $.10 ; \mathrm{P}=.287)$ and (Beta $=-.03 ; \mathrm{P}=.820)$ respectively. These non significant coefficients indicate that these variables do not contribute much to the model.

Though, Operations as a citizen, proved to be significant predictor of organizational citizenship behaviour, results divulged that; interpersonal relations, Intellectual operations, Behavioural and emotional stability, Adequacy of communication do not significantly predict organizational citizenship behaviour. It can be concluded from the results that, operations as a citizen has the largest beta coefficient (.25), whereas, ethical \& moral strength has 
the smallest beta coefficient (-.03). This also means that, one standard deviation increase in operations as a citizen leads to .25 standard deviation increase in predicted organizational citizenship behaviour and one standard deviation increase in ethical and moral strength leads to .03 decrease in organizational citizenship behaviour. The R square was found to be .21, which means that, all the predictor variables, account for approximately $21 \%$ variance of organizational citizenship behaviour. As a whole, regression does a good job of modelling organizational citizenship behaviour. F value was found as $8.943(\mathrm{P}=.000)$, which indicates that model is significant and variation in organizational citizenship behaviour is because of leadership and is not due to chance.

\section{Ha 4: Personality is a predictor of organizational citizenship behaviour.}

To examine the cause and effect relationship between personality and organizational citizenship behaviour, linear regression was performed. Results of linear regression disclosed that Personality is significantly positively associated with Organizational citizenship behaviour. As can be seen from the Table 4.1, standardized beta coefficient is $.33(\mathrm{P}=.000)$ which means that, one standard deviation increase in personality would yield a .331 standard deviation increase in the predicted organizational citizenship behaviour. Thus, this beta coefficient shows that the association between personality and organizational citizenship behaviour is significant. The result further indicates that the direction of the association is positive which means that, employees who are emotionally stable, highly conscientious, open to new experiences; extraverted and highly agreeable are more likely to engage in organizational citizenship behaviour. On the other hand, employees who are low on these traits are less likely to engage in organizational citizenship behaviour. 
Table 4.1: Regression Analysis showing Organizational Citizenship Behaviour as Dependent Variable and Personality as Predictor variable

\begin{tabular}{|l|c|c|c|c|c|c|}
\hline $\begin{array}{l}\text { Regression } \\
\text { Model }\end{array}$ & $\mathrm{R}$ & $\begin{array}{c}\mathrm{R} \\
\text { Square }\end{array}$ & $\begin{array}{c}\text { Adjusted R } \\
\text { Square }\end{array}$ & F-value & Df & $\begin{array}{c}\text { Beta } \\
\text { Value }\end{array}$ \\
\hline $\begin{array}{l}\text { Dependent } \\
\text { Variable: }\end{array}$ & & & & & & \\
$\begin{array}{l}\text { Organizational } \\
\text { Citizenship } \\
\text { Behaviour }\end{array}$ & 0.33 & 0.11 & 0.10 & $24.769^{* *}$ & 1,201 & 0.33 \\
\hline
\end{tabular}

\section{** Significant at $1 \%$ level}

$\mathrm{R}$ square is meant to explain the strength of the connection between predictor and dependent variable. In this case, it is personality and organizational citizenship behaviour. The $\mathrm{R}$ square is .11, which implies that approximately $11 \%$ of the variance of organizational citizenship behaviour is accounted for by the predictor variable that is personality. As can be seen in the Table 4.1, computed $\mathrm{F}$ value is $24.769(\mathrm{P}=.000)$ and its significance value is less than 0.01 , which means that variation explained by the predictor, that is, personality is not due to chance. In other words, variation in organizational citizenship behaviour is only because of personality and nothing else.

Further, linear regression was performed to model the value of organizational citizenship behaviour, based on its relationship to a set of predictors that is dimensions of personality. Results of linear regression illustrated that personality is a significant predictor of organizational citizenship behaviour. So further, aim was to investigate whether five dimensions of personality also predict organizational citizenship behaviour.

Results of this study demonstrated that out of five, only one dimension of personality is a significant predictor of organizational citizenship behaviour. The results of this study exemplify that association between conscientiousness and organizational citizenship behaviour is significant with beta coefficient $=.50(\mathrm{P}=$ $.000)$. The direction of association is positive, which indicates that, employees who score high on conscientiousness will show higher organizational citizenship behaviour than employees who score 
low on organizational citizenship behaviour. People who are high in conscientiousness generally perform their part of work with a minimum of oversight, and are dependable, efficient and hardworking. It is this kind of highly conscientious employees who are more likely to engage in organizational citizenship behaviour.

However, no strong association was observed between Neuroticism, Extraversion, Openness to experience, Agreeableness and organizational citizenship behaviour. This is evident from the Beta coefficients, which were found to be (beta $=-.13 ; \mathrm{P}=.052$ ), $($ beta $=.08 ; \mathrm{P}=.242),($ beta $=-.05 ; \mathrm{P}=.366),($ beta $=-.07 ; \mathrm{P}=.301)$ for Neuroticism, Extraversion, Openness to experience and Agreeableness respectively. They indicate that these four variables do not contribute much to the model. Except for Conscientiousness and Extraversion, the direction of association between Neuroticism, Openness to experience and Agreeableness was found to be negative. This implies that employees who are emotionally unstable, open to new experiences and highly agreeable do not engage much in organizational citizenship behaviour. It can be concluded from the results that conscientiousness has the largest beta coefficient (.50) and openness to experience has the smallest beta coefficient (-.05). This means that one standard deviation increase in conscientiousness leads to .50 standard deviation increases in organizational citizenship behaviour, and one standard deviation decrease in openness to experience leads to .05 standard deviation increases in organizational citizenship behaviour.

Though, Conscientiousness proved to be a significant predictor of organizational citizenship behaviour, results exemplified that Neuroticism, Extraversion, Openness to experience and Agreeableness do not significantly predict organizational citizenship behaviour. The $\mathrm{R}$ square is .34 , which means that, all five predictor variables, account for approximately $34 \%$ variance of organizational citizenship behaviour. As a whole, regression does a good job of modelling organizational citizenship behaviour. F value was found to be 20.260 ( $\mathrm{P}=.000)$, which indicates that model is significant and variation in organizational citizenship behaviour is not due to chance.

The results of this study are congruent with the findings of Kumar, Bakshi (2009); Elanain (2007), who in their studies reported that, 
Conscientiousness is a valid predictor of organizational citizenship behaviour. Especially, Kumar \& Bakshi (2009) in their study found agreeableness, emotional stability and extraversion as valid predictors of organizational citizenship behaviour. However, in the current study, they did not prove to be valid predictors.

\section{Ha 5: There is a significant influence of Job tenure on Organizational Citizenship Behaviour.}

Results of One Way Anova revealed that significant difference exists in organizational citizenship behaviour, as a result of Job Tenure. As shown in Table 5.1, F value was found to be 2.41 ( $\mathrm{P}=$ .038 ), which is significant at 0.05 level of significance. This indicates that, an extent to which an employee engages in such discretionary and spontaneous behaviour depends on number of years an employee has spent in that organization.

Table 5.1: The sum of squares, degrees of freedom, mean squares and f-value with regards to the different groups based on organizational tenure (Organizational Citizenship Behaviour)

\begin{tabular}{|l|c|c|c|c|}
\hline $\begin{array}{c}\text { Organizational } \\
\text { Tenure Groups } \\
\mathbf{( N = 2 0 3 )}\end{array}$ & $\begin{array}{c}\text { Sum of } \\
\text { Squares }\end{array}$ & df & $\begin{array}{c}\text { Mean } \\
\text { Square }\end{array}$ & F-value \\
\hline Between Groups & 1488.227 & 5 & 297.645 & $2.41^{*}$ \\
\hline Within Groups & 24278.236 & 197 & 123.240 & - \\
\hline Total & 25766.463 & 202 & - & - \\
\hline
\end{tabular}

* Significant at $5 \%$ level

Though significant difference was observed on overall Organizational Citizenship Behaviour as a result of job tenure, results of dimension wise analysis revealed significant difference on just one dimension of OCB, which is Conscientiousness. F value for Conscientiousness was found to be $2.92(\mathrm{P}=.014)$, which is significant at 0.05 level of significance. However, $\mathrm{F}$ values for other four dimensions, namely; Courtesy $(\mathrm{F}=.92)$, Sportsmanship $(\mathrm{F}=$ $.34)$, Helping Co-worker $(\mathrm{F}=.52)$ and Civic Virtue $(\mathrm{F}=.13)$ proved to be insignificant.

Using Pearson's Product Moment Correlation Method, correlation coefficient was also computed to determine whether there exist a 
relationship between job tenure and organizational citizenship behaviour. Correlation coefficient was found to be .18 which is significant at $1 \%$ level of significance, thereby indicating a positive correlation. This means that, as employee's job tenure increases, organizational citizenship behaviour also increases and it decreases with a shrink in job tenure. This insinuates that employees with longer tenure will show more organizational citizenship behaviour, in contrast to employees with lower tenure. One possible explanation for this is that, Organizational Citizenship Behaviours are behaviours that are internally motivated, arising from within and sustained by an individual's intrinsic need for a sense of achievement, competence, belonging or affiliation. As an employee spends years in the Company, he becomes more committed to the organization, develops a sense of attachment towards organization and its member, becomes more loyal to the organization and also starts identifying himself with the organization. So, in turn, this feeling of belongingness motivates employees to engage in organizational citizenship behaviour.

A descriptive analysis of the data revealed that, employees with job tenure of 20-24 yrs $(M=99.82)$ showed higher organizational citizenship behaviour, followed by employees with tenure of 15-19 yrs $(\mathrm{M}=99.02), 25 \&$ above $(\mathrm{M}=97.67), 5-9 \mathrm{yrs}(\mathrm{M}=95.40), 0-4$ yrs $(\mathrm{M}=94.82)$ and lastly $10-14$ yrs $(\mathrm{M}=88.50)$. Thus, employees with job tenure ranging between 10-14 yrs were found to engage in organizational citizenship behaviour to a much lesser extent.

In fact, dimension wise descriptive analysis divulged that, except for the dimension of helping co-worker and civic virtue, employees in job tenure range of 20-24 yrs were found to be more conscientious and displayed more of courtesy and sportsmanship behaviours as compared to employees with other job tenures. However, helping and civic virtue behaviour was found to be high among employees with job tenure of 15-19 yrs.

On the other hand, employees in the job tenure range of 10-14 yrs were found to be less conscientious and also showed less courtesy, sportsmanship and civic virtue behaviour. Only on one dimension, employees in job tenure range of 20-24 yrs scored low, thereby indicating that, they are less likely to engage in helping behaviour. 
The results of this study support previous research (Morrison, 1994), which also linked tenure to dimensions of organizational citizenship behaviour and found that tenure significantly influences OCB.

\section{Ha 6: Educational qualification of employees significantly affects Organizational Citizenship Behaviour.}

As hypothesized, significant difference was observed in organizational citizenship behaviour, depending on the educational qualification of employees. F value was computed using One Way Anova, which was found to be $2.96(\mathrm{P}=.033)$ and is significant at 0.05 level of significance. This implies that, whether or not employees will make contributions that are beyond specified task performance depends on their level of education too.

Further, results of dimension wise analysis revealed that though, overall organizational citizenship behaviour depends on educational level, not all of its dimensions do. In fact, out of five, significant difference was noticed only on two dimensions of organizational citizenship behaviour as a result of educational qualification. On the dimension of Conscientiousness, $\mathrm{F}$ value was computed as $3.47(\mathrm{P}=.017)$ and on Civic Virtue $\mathrm{F}$ value was found to be $2.72(\mathrm{P}=.046)$ both of which proved significant at 0.01 level of significance. However, no significant difference was observed on other three dimensions, namely, Courtesy $(\mathrm{F}=1.90$; $\mathrm{P}=.130)$, Sportsmanship $(\mathrm{F}=1.49 ; \mathrm{P}=.218)$, and Helping co worker $(\mathrm{F}=$ $1.15 ; \mathrm{P}=.330)$.

Table 6.1: The sum of squares, degrees of freedom, mean squares and f-value with regards to the different groups based on education (Organizational Citizenship Behaviour)

\begin{tabular}{|l|c|c|c|c|}
\hline $\begin{array}{c}\text { Education groups } \\
(\mathbf{N}=\mathbf{2 0 3})\end{array}$ & $\begin{array}{c}\text { Sum of } \\
\text { Squares }\end{array}$ & df & $\begin{array}{c}\text { Mean } \\
\text { Square }\end{array}$ & $\begin{array}{c}\text { F- } \\
\text { value }\end{array}$ \\
\hline Between Groups & 1100.832 & 3 & 366.944 & $2.96^{*}$ \\
\hline Within Groups & 24665.631 & 199 & 123.948 & - \\
\hline Total & 25766.463 & 202 & - & - \\
\hline
\end{tabular}

* Significant at $5 \%$ level

A descriptive analysis of the data revealed some interesting findings. Employees who had completed their HSSC ( $M=98.96)$ 
were found to be showing higher Organizational Citizenship Behaviour followed by employees with post graduation $(\mathrm{M}=$ 98.91), and then Graduate employees $(M=95.91)$. Whereas, those with SSC ( $\mathrm{M}=92.41)$ were found as less likely to engage in organizational citizenship behaviour. As can be seen in the Figure 5.11, means of HSSC/diploma holders and post graduates are almost the same, which means that both show same level of organizational citizenship behaviour.

Dimension wise analysis however, provided an interesting insight. On conscientiousness, HSSC/Diploma passed $(\mathrm{M}=32.44)$ and post graduate $(\mathrm{M}=32.25)$ employees, were found to be most conscientious and SSC passed (29.78) employees to be least Conscientious.

However, postgraduate employees $(\mathrm{M}=19.69)$ showed highest courteous behaviour, followed by Graduate employees $(M=19.01)$, HSSC/Diploma holders $(\mathrm{M}=18.83)$ and lastly Matriculate employees $(M=17.83)$.

Thirdly, Postgraduate employees were found to show higher sportsmanship behaviour $(\mathrm{M}=18.63)$, followed by HSSC/Diploma holders $(M=17.35)$, than Graduates $(M=16.63)$ and finally SSC passed employees $(\mathrm{M}=16.34)$.

Findings also revealed that, Diploma holders engage in helping behaviour more frequently $(M=16.62)$, followed by Graduates $(M$ $=16.04)$, than postgraduates $(\mathrm{M}=15.63)$ and lastly SSC passed employees $(M=15.56)$.

Lastly, civic virtue was discovered as high among HSSC/Diploma holders $(\mathrm{M}=13.73)$, followed by SSC passed employees $(\mathrm{M}=$ 12.90), then Graduates (12.69) and lastly Post Graduate employees (12.63).

Thus, significant difference was found in OCB based on educational qualifications, with HSSC/Diploma holders and Postgraduates showing higher organizational citizenship behaviour. One probable reason for this is that Post graduate employees are mostly ones in higher positions. So they engage in Organizational citizenship behaviour because their subordinates (graduates) follow and imitate them. Whereas, HSSC/Diploma 
holders act as in charges over SSC passed employees, hence they display such discretionary behaviours. They are mostly in supervisory positions, so they engage in helping acts like helping new employee on utilization of equipment etc., because their position demands them to do so.

These findings are consistent with those of Hopkins, 2002 who examined in his study, the effects of leadership and various organizational outcomes on child and family service employees' willingness to engage in OCB. Survey data showed employees' reports of organizational support, job performance and educational qualification were positively related to employees' OCB.

\section{Ha 7: Age of employees significantly affects Organizational Citizenship Behaviour.}

No significant difference was noticed in organizational citizenship behaviour across different age groups. Using One Way Anova F value was computed to investigate whether age has any influence on willingness to engage in organizational citizenship behaviour. But derived $\mathrm{F}$ value proved to be insignificant $(\mathrm{F}=2.46 ; \mathrm{P}=.064)$.

Table 7.1: The sum of squares, degrees of freedom, mean squares and f-value with regards to the different age groups (Organizational Citizenship Behaviour)

\begin{tabular}{|l|c|c|c|c|}
\hline \multicolumn{1}{|c|}{$\begin{array}{c}\text { Age Groups } \\
(\mathbf{N}=\mathbf{2 0 3})\end{array}$} & $\begin{array}{c}\text { Sum of } \\
\text { Squares }\end{array}$ & df & $\begin{array}{c}\text { Mean } \\
\text { Square }\end{array}$ & F-value \\
\hline Between Groups & 921.526 & 3 & 307.175 & 2.46 \\
\hline Within Groups & 24844.937 & 199 & 124.849 & - \\
\hline Total & 25766.463 & 202 & - & - \\
\hline
\end{tabular}

Further, dimension wise analysis was done to investigate whether age has any influence on any of the dimension of $O C B$, if not overall OCB. But again, results obtained were contrary to what was hypothesized. None of the dimensions of OCB were found to differ significantly, as a result of age. $\mathrm{F}$ values for Conscientiousness $(\mathrm{F}=$ 2.57; $\mathrm{P}=.055)$, Courtesy $(\mathrm{F}=.07 ; \mathrm{P}=.974)$, Sportsmanship $(\mathrm{F}=1.95$; $\mathrm{P}=.123)$, Helping co worker $(\mathrm{F}=.29 ; \mathrm{P}=.835)$ and Civic Virtue $(\mathrm{F}=$ 2.28; $\mathrm{P}=.081$ ) were found to be insignificant. Thus, findings imply that age does not have a major significant influence on organizational citizenship behaviour. Employees from all the age 
groups (20-29 yrs, 30-39 yrs, 40-49 yrs and 50-59 yrs) engage in organizational citizenship behaviour almost to the same extent. So, age does not play a pivotal role in determining whether employees will engage in OCB or not.

A descriptive analysis of the data was done to find out if not significant than any minor difference exist in Organizational citizenship behaviour across age groups. Results revealed that employees belonging to the age groups $50-59$ yrs $(M=100.00)$ and 40-49 yrs $(\mathrm{M}=97.24)$ show higher organizational citizenship behaviour as compared to employees in the age groups of 20-29 yrs $(M=95.07)$ and 30-39 yrs $(M=93.14)$. Similar results were obtained on all the dimensions of Organizational Citizenship Behaviour.

Table 7.2: Mean and standard deviation of organizational citizenship behaviour based on age

\begin{tabular}{|l|c|c|c|}
\hline \multicolumn{4}{|c|}{ Organizational Citizenship Behaviour } \\
\hline \multicolumn{1}{|c|}{ Age (years) } & $\mathbf{N}$ & Mean & Std. Deviation \\
\hline $20-29$ yrs & 86 & 95.07 & 10.023 \\
\hline $30-39$ yrs & 28 & 93.14 & 19.204 \\
\hline $40-49$ yrs & 55 & 97.24 & 10.323 \\
\hline $50-59$ yrs & 34 & 100.00 & 10.243 \\
\hline Total & 203 & 96.22 & 11.294 \\
\hline
\end{tabular}

One possible explanation for this difference is that, early years (2040) are the years of establishment and settling down; later years (40-60) are strong sense of self and location vis-a-vis life and work. Especially, younger employees coordinate their needs with organizational needs more flexibly; by contrast, older employees tend to be more rigid in adjusting their needs with the organization. Therefore, younger and older workers might differ in their orientations toward self, others, and work. These differences might lead to different salient motives for OCB among younger and older employees.

Using Pearson's Product moment correlation, correlation between age and organizational citizenship behaviour was calculated to see whether any relationship exists between the two. Correlation coefficient was found to be .14, which is significant at $5 \%$ level of significance. Thus, this coefficient signifies a positive correlation, 
which means that increase in age brings about increase in organizational citizenship behaviour. But as age decreases, organizational citizenship behaviour also decreases.

This might be probably because, most of the older employees are well experienced and properly settled in their jobs and the organization. They also serve as role models who are imitated and followed by younger employees. In fact, older employees are more responsible and have vast knowledge resource. All these compels them to engage in varied helping behaviours like helping new employees, being on time, being punctual, attending all the meetings, maintaining respectful relations with fellow workmen, helping others in avoiding problems to occur etc.

The results of this study are contradictory to what previous researches had found. Morrison, 1994 in his study found that age significantly influences dimensions of organizational citizenship behaviour. Deckop et al., 1999 for instance reported that age of employee had negative and marginally significant effect on organizational citizenship behaviour.

\section{Ha 8: Designation of employees significantly affects Organizational Citizenship Behaviour.}

Results obtained from One Way Anova, divulged that, no significant difference exists among higher, middle and lower level employees with regard to organizational citizenship behaviour. F value computed is $2.19(\mathrm{P}=.114)$ which proved to be insignificant. Results signify that, no matter to which level an employee belongs; higher, middle or lower, organizational citizenship behaviour is almost the same among higher, middle and lower level employees.

Table 8.1: The sum of squares, degrees of freedom, mean squares and f-value with regards to the different groups based on designation (Organizational Citizenship Behaviour)

\begin{tabular}{|l|c|c|c|c|}
\hline $\begin{array}{c}\text { Designation wise Groups } \\
(\mathbf{N}=\mathbf{2 0 3})\end{array}$ & $\begin{array}{c}\text { Sum of } \\
\text { Squares }\end{array}$ & Df & $\begin{array}{c}\text { Mean } \\
\text { Square }\end{array}$ & $\begin{array}{c}\text { F- } \\
\text { value }\end{array}$ \\
\hline Between Groups & 554.119 & 2 & 277.059 & 2.19 \\
\hline Within Groups & 25212.344 & 200 & 126.062 & - \\
\hline Total & 25766.463 & 202 & - & - \\
\hline
\end{tabular}


Further, dimension wise analysis also revealed similar findings. F values for none of the dimension of organizational citizenship behaviour were found significant. This implies that there is no significant difference among higher, middle and lower level employees with regard to dimensions of organizational citizenship behaviour also. $\mathrm{F}$ value for Conscientiousness was found to be 1.17 $(\mathrm{P}=.182)$, Courtesy $(\mathrm{F}=2.47 ; \mathrm{P}=.087)$, Sportsmanship $(\mathrm{F}=1.12 ; \mathrm{P}$ $=.328)$, Helping co worker $(\mathrm{F}=.95 ; \mathrm{P}=.389)$ and Civic Virtue $(\mathrm{F}=$ $.37 ; \mathrm{P}=.689)$.

Data was further analyzed to investigate whether, if not significant than at least minor difference exist in organizational citizenship behaviour across higher, middle and lower level employees.

Table 8.2: Mean and standard deviation of organizational citizenship behaviour based on designation

\begin{tabular}{|l|c|c|c|}
\hline \multicolumn{4}{|c|}{ Organizational Citizenship Behaviour } \\
\hline Designation & N & Mean & Std. Deviation \\
\hline Higher & 62 & 98.52 & 9.462 \\
\hline Middle & 69 & 95.99 & 8.188 \\
\hline Lower & 72 & 94.46 & 14.628 \\
\hline Total & 203 & 96.22 & 11.294 \\
\hline
\end{tabular}

Results revealed that higher level employees $(M=98.52)$ show higher organizational citizenship behaviours as compared to middle $(\mathrm{M}=95.99)$ and lower level $(\mathrm{M}=94.46)$ employees. Mean scores of higher level employees were found to be high as compared to middle and lower level employees on dimensions of conscientiousness $(M=32.24)$, Sportsmanship $(M=17.53)$, Helping co worker $(\mathrm{M}=16.47)$ and Civic virtue $(\mathrm{M}=13.18)$. Only on the courtesy dimension, mean scores of middle level ( $\mathrm{M}$ - 19.17) employees were found to be high.

One probable reason for this is that, higher level employees consist of senior officer, managers and above. They are more conscientious, as in come regularly at the workplace, are on time, show low absenteeism levels, because this is what their position demands from them. Lower and middle level employees imitate their higher ups. If higher level employees are not regular or disobey the rules, 
than their subordinates will do the same thing. This is why higher level employees are slightly higher on conscientiousness.

Secondly, higher level employees show more sportsmanship behaviour, i.e. they refrain from exaggerating problems, avoid tension or quarrel, maintain respectful relations with fellow workmen. Whenever, conflicts arise in the workplace higher level employees have to resolve them and ensure that harmonious environment is maintained at the workplace. So to do, they engage in sportsmanship behaviours.

Thirdly, higher level employees engage more in civic virtue behaviours like showing interest in policies of the organization or delivering opinions for strategies of the organization or helping behaviours like sharing burden of fellow workmen, because their position itself requires them to do so. Main point is that, lower level employees follow their authorities. Authorities therefore have to display proper behaviour so as to imbibe proper values in their employees.

Mean scores of lower level employees however were found to be low on dimensions of Conscientiousness $(\mathrm{M}=30.92)$, Courtesy ( $\mathrm{M}$ $=18.13)$ and Sportsmanship $(\mathrm{M}=16.46)$. This is probably because it's a common scenario in the organizations that lower level employees, mainly workers are not regular at the work, absenteeism levels are high, they engage in acts of cheating, complain about work and organizational systems \& processes, quarrel with fellow workmen etc. As these acts and behaviours are related to dimensions of courtesy, sportsmanship and conscientiousness, lower level employees scored low on these three dimensions also. On the dimensions of Helping co worker $(\mathrm{M}=$ 15.78) and Civic Virtue $(M=12.84)$, mean scores of middle level employees were found to be low.

\section{Ha 9: There is an influence of gender on Organizational Citizenship Behaviour.}

Contrary to what was hypothesized, results of $t$ test indicated no significant gender differences in organizational citizenship behaviour. T value was found to be $.62(\mathrm{P}=.536)$ which proved to be insignificant. This signifies that males and females engage in organizational citizenship behaviour to a same extent. 
The findings of this study are consistent with those of Organ and Ryan (1995) \& Ahmad (2006), who also didn't report any significant influence of gender on organizational citizenship behaviour in their studies.

Table 9.1: Comparison of organizational citizenship behaviour based on gender

\begin{tabular}{|l|c|c|c|c|}
\hline \multicolumn{1}{|c|}{ Gender } & $\mathbf{N}$ & Mean & SD & t-value \\
\hline Male & 167 & 95.99 & 11.916 & \multirow{2}{*}{0.62} \\
\cline { 1 - 4 } Female & 36 & 97.28 & 7.833 & \\
\hline
\end{tabular}

Further, dimension wise analysis was done to determine whether significant difference exist on any dimension of organizational citizenship behaviour among males and females. Results revealed that males and females differ on only one dimension of organizational citizenship behaviour, that is, Sportsmanship. $\mathrm{T}$ value on this dimension was found to be 2.001 ( $\mathrm{P}=.047)$, which is significant at 0.05 level of significance. No significant difference was noticed on other four dimensions of organizational citizenship behaviour namely, Conscientiousness $(\mathrm{T}=-.44 ; \mathrm{P}=.661)$, Courtesy $(\mathrm{T}=1.17, \mathrm{P}=.242)$, Helping co worker $(\mathrm{T}=-.45, \mathrm{P}=.655)$ and Civic virtue $(\mathrm{T}=-.81, \mathrm{P}=.418)$.

Findings are contrary to what earlier researches had stated. Finkelstein \& Farrell (2007) for instance had stated that women are more likely to participate in the helping dimension of organizational citizenship behaviour (OCB) whereas men are more likely to participate in the civic virtue dimension. Rush \& Allen (2001) also stated that, an abundant body of social psychological research indicates that there are gender differences with regard to helping behaviour and altruism.

Further, descriptive analysis of the data showed that, though no significant gender differences were observed, females $(M=97.28)$ engage more in organizational citizenship behaviour as compared to males $(M=95.99)$. This means that females are more likely to engage in voluntary and discretionary actions which go beyond the explicit role requirements. One possible explanation for this is that, women by nature are warm, kind, helpful and understanding. So, they are more likely to engage in various helping or altruistic 
behaviours. Whereas males have some impression management motives behind engaging in organizational citizenship behaviour. (Finkelstein \& Farrell, 2007)

As mentioned before, significant gender differences were noticed on dimension of sportsmanship. Females $(M=18.17)$ were found to show higher sportsmanship behaviour, as compared to males $(\mathrm{M}=$ 16.64). This means that females mostly refrain from exaggerating problems when they exist, refrain from complaining about the work, do not blame somebody at the workplace, are able to tolerate organizational problems, behave in such a way to avoid any tension or quarrel with fellow workmen during the times of crisis and are always respectful in relations with fellow workmen.

On the other four dimensions however, no significant difference was observed. But minor differences were noticed. On the dimension of courtesy, females $(M=19.33)$ were found to have higher mean scores than males $(M=18.66)$. Whereas, on the other three dimensions, that is conscientiousness, helping co worker and civic virtue males were found to have higher mean scores $(\mathrm{M}=$ 31.53), $(M=16.10),(M=13.05)$ respectively, as compared to females $(M=31.19),(M=15.86)$ and $(M=12.72)$.

However, in general, results of this study are contradictory to findings of previous studies (Allen, 2006; Morrison, 1994; Chang, 1995; Diefendorff, Kamin and Lord, 2002) who found and reported that gender is associated with extra role behaviour. One probable explanation for this is that, sample of this study was chosen from a mining Company. Mining companies do not employ many female employees. So, sample consisted of less female employees i.e. 36 and more male employees i.e. 167.

\section{Ha 10: Job Status of employees significantly affects Organizational Citizenship Behaviour.}

Using independent samples $\mathrm{t}$ test, $\mathrm{t}$ values were computed to find out whether, temporary and permanent employees engage in different levels of organizational citizenship behaviour. Results revealed no such significant difference among temporary and permanent employees. This is evident through $t$ value which was found to be $-1.08(\mathrm{P}=.282)$, which proved to be insignificant. 
Findings imply that willingness to engage in organizational citizenship behaviour is not altered by job status of the employees.

Further, all dimensions were analysed to see whether difference exist on any of the dimension, if not overall organizational citizenship behaviour. But no such differences were found. T values for all the dimensions were found insignificant. $T$ values obtained are; Conscientiousness $(\mathrm{t}=-1.58, \mathrm{P}=.115)$, Courtesy $(\mathrm{t}=$ $.93, \mathrm{P}=.351)$, Sportsmanship $(\mathrm{t}=-1.56, \mathrm{P}=.121)$, Helping co worker $(\mathrm{t}=-.19, \mathrm{P}=.846)$ and Civic Virtue $(\mathrm{t}=-.65, \mathrm{P}=.514)$.

Table 10.1: Comparison of organizational citizenship behaviour based on job status

\begin{tabular}{|c|c|c|c|c|}
\hline Job Status & $\mathbf{N}$ & Mean & SD & t-value \\
\hline Temporary & 35 & 94.34 & 11.332 & \multirow{2}{*}{-1.08} \\
\hline Permanent & 168 & 96.61 & 11.281 & \\
\hline
\end{tabular}

Though, no significant differences were evident, certain minor differences were observed among temporary and permanent employees with regard to organizational citizenship behaviour. Permanent employees were found to have slightly higher mean scores $(\mathrm{M}=96.61)$ on overall organizational citizenship behaviour, as compared to temporary employees $(\mathrm{M}=94.34)$. When dimension wise analysis was done, permanent employees were found to have higher mean scores on four dimensions namely, Conscientiousness $(\mathrm{M}=31.68)$, Sportsmanship $(\mathrm{M}=17.12)$, Helping co worker $(\mathrm{M}=$ 16.08) and Civic Virtue $(M=13.04)$ as compared to temporary employees $(M=30.46)$, $(M=15.91),(M=15.97),(M=12.77)$. Only on the dimension of Courtesy, temporary employees obtained higher mean scores $(\mathrm{M}=19.23)$, as compared to permanent employees $(M=18.68)$.

Results of this study partially support previous research by Van Dyne \& Ang, (1998) who in their study of professional bankers and hospital employees found that contingent workers engaged in fewer OCBs and had lower affective commitment to their organizations. They argued that there would be less pressure for contingent employees, who receive fewer tangible and intangible rewards from their employing organizations, to perform OCB when the market is one in which there are severe shortages of 
labour and when their choice of contingent job status would be more likely to be voluntary.

However, temporary employees were found to have higher mean scores on one dimension. The probable explanation is well offered by Feather and Rauter (2004) who argued that in labor markets where organizations are downsizing or where there is an oversupply of jobs in a particular area, workers would be more likely to enter contingent work arrangements involuntarily. Contingent employees on short term contracts might then perform OCB in the expectation that their doing so would enhance their image as valued employees, thereby increasing their chances of being made permanent within organization. These findings however are contradictory to those of Van Dyne \& Ang, 1998.

However, limited research is available on comparison between OCB of contingent and permanent employees; the available research, too, provides contradictory results (e.g., Cappelli, 1995; Chang \& Chelladurai, 2003; Feather \& Rauter, 2004; Kidder, 1995; Pearce, 1993; Van Dyne \& Ang, 1998).

Data was analyzed using $t$ test and one way Anova and the results did not find any significant difference of age, designation, educational qualifications, job tenure, gender \& job status on leadership and its six dimensions and

\section{Implications of the study}

The implications to the human resource management and organizational behaviour are numerous. The interest in leadership, personality and organizational citizenship behaviour at work has been the central focus. Organizations can formulate practices which enhances leadership, personality and organizational citizenship behaviour.

The use of personality tests in employee selection will increase the likelihood to select job candidates with predisposition to exhibit OCB which will help improve organizational effectiveness. During selection process, interviewer can test for those traits or personality characteristics that have been shown to be predictors of OCB. For example, interviewers can use measures of conscientiousness as research suggests that this personality characteristic is associated 
with generalized compliance, job dedication and organizational citizenship behaviour.

Situational Interviews and assessment centres can assess personal relations, such as sociability and verbal fluency, and good citizenship, such as dependability, conscientiousness, stability and perseverance". Situational interview can be an effective way to assess the propensity to engage in OCB. Assessment team can design activities that give people an opportunity to exhibit helpfulness, voice, sportsmanship and so on.

For leader to be effective there must be an adequate and reasonably well balanced development of the following qualities in a supervisor: Thoroughness: A supervisor should collect all the information relevant to the issue and take care of every necessary detail. Fairness: This includes a sense of justice, considerations and truthfulness towards workers. Initiative: This is a combination of three qualities of courage, self confidence and decisiveness. Tact: It is the ability to win the loyalty and support of others by saying and doing those things, which give them a feeling that they are playing an important part in whatever is being done. Enthusiasm: It is an intense and eager interest in and devotion to a cause, a pursuit or an ideal. It includes interest, knowledge and achievement. Emotional Control: It means not the elimination of emotions but rather to control and channel them in right direction. Clarity of Communication: Employees seldom disobey an order. It is generally not communicated to them with clarity. This leads to confusion and lack of confidence. Communication should be simple, clear, direct and with a calm voice. Know your employees personally: If leader desires to motivate the employees, he should know them personally and strengthen his relationship with them. It will give leader a very effective line of communication with them. Leader must call them by name and should be aware of any family problems an employee may have. Teach them discipline by setting example: Leader must lead employees with a flag in his hand. Leaders must set them a good example of discipline by their own actions. When leader's talk, employees listen, and when leaders act they watch. Just as speed of the engine is the speed of the train, likewise the speed of the boss is the speed of the team. Leader has to be patient and give followers' sufficient time to 
absorb his philosophy. Open communication: Leaders must frequently communicate with their subordinates. They should be informed about policy changes, reasons for taking certain decisions should be explained to them and group's reaction should be checked before going ahead with new plan.

The implementation of these ideals will, of course, present the management with considerable challenges which is however a norm for continuous growth.

\section{Limitations and Suggestions for Future Research}

As with any research, the current study undoubtedly has certain limitations that must be noted.

Firstly, OCB was measured subjectively by employees not by their superiors or peers.

Secondly, common variance problems cannot be ruled out since data on both independent and dependent variables were collected at the same time and using the self report measures.

Third limitation is based upon methodology, because data were collected from three units of only one organization. Therefore, this study may not be generalizable to other organizational settings.

Replication is needed to determine how the findings reported here correspond to the results of studies conducted in other work environments to ensure proper generalizability. Future OCB researchers should examine the relationship between $O C B$ and other antecedent and outcome variables found to be important in previous organizational behaviour research in order to look at a broader organizational environment in attributing organizational citizenship behaviour. Researchers can consider the moderating influences of person and situation based factors on the relationship between organizational climate, leadership, personality and organizational citizenship behaviour. Self ratings accompanied with peer or superior ratings to get a measure of OCB will increase the validity of the behaviour and longitudinal research might be recommended for future research. 


\section{Conclusion}

In sum, the findings of this study suggest that when assessing how effective one is in engaging organizational citizenship behaviour, perceived leadership effectiveness and big five personality domains will be important predictors. The results of correlation analysis divulged significant positive correlation between leadership, personality and organizational citizenship behaviour. Regression analysis unveiled that leadership and personality are important predictors of organizational citizenship behaviour. Results of $t$ test and One Way Anova, disclosed that organizational tenure and educational qualifications exert significant influence on organizational citizenship behaviour. However, age, designation, gender and job status did not show any noteworthy influence on organizational citizenship behaviour. No influence was noticed of any of the incidental variables on leadership \& its dimensions.

\section{References}

Ahmad, Z. B. (2006). Job attitudes as a determinant of organizational citizenship behaviours: A study among academic staff in Kuching Polytechnic. Available from ProQuest Dissertations and Theses database.

Ali, A., Abu, D. S., Aminah, A., Bahaman, A. S. (2008). The relationship between transformational leadership behaviours, organizational justice, leader-member exchange, perceived organizational support, trust in management and organizational citizenship behaviors. European Journal of Scientific Research, 23(2), 227-242.

Allen, J., Meyer, N. (1996). Affective, continuance and normative commitment to the organization: An examination of construct validity. Journal of Vocational Behaviour, 49, 252-276.

Allen, T. D. (2006). Rewarding good citizens: The relationship between citizenship behavior, gender, and organizational rewards. Journal of Applied Social Psychology, 36, 120-143.

Allen, T., Rush, M. (2001). The Influence of Ratee Gender on Ratings of Organizational Citizenship Behavior'. Journal of Applied Social Psychology, 31(12), 2561-2587.

Asgari, A., Silong, A. D., Ahmad, A., Samah, B. A. (2008). The Relationship between Organizational Characteristics, Task Characteristics, Cultural Context and Organizational Citizenship 
Behaviours. European Journal of Economics, Finance and Administrative Sciences, 13.

Asgari, A., Silong, A. D., Ahmad, A., Samah, B. A. (2008). The Relationship between Transformational Leadership Behaviours, Leader-Member Exchange and Organizational Citizenship Behaviours. European Journal of Social Sciences, 6(4).

Bakhshi, A., Kumar, K. (2009). National culture and organizational citizenship behavior: Development of a scale. Organisation Behaviour. New Delhi: Global Publishing House

Barnard, G. A., Jenkins, G. M., Winsten, C. B. (1962). Likelihood Inference and Time Series, Journal of the Royal Statistical Society, Series A, 125, 321-372.

Barrick, M. R., Mount, M. K. (1991). The big five personality dimensions and job performance: A Meta Analysis. Personnel Psychology, 44, 1-26.

Barrick, M. R., Mount, M. K., Judge, T. A. (2001). Personality and performance at the beginning of the new millennium: What do we know and where do we go next? Personality and Performance, 9, 9-30.

Bateman, T. S., Organ, D. W. (1983). Job Satisfaction and the Good Soldier: The Relationship between Affect and Employee Citizenship. Academy of Management Journal, 26, 587-595.

Bukhari, Z. U. (2008). Key Antecedents of Organizational Citizenship Behavior (OCB) in the Banking Sector of Pakistan. International Journal of Business and Management, 3(12).

Cappelli, P. (1995). Re-thinking employment. British Journal of Industrial Relations, 33, 563-602.

Chang, E. (1995). A comparative study on organizational commitment: The case of regular and non-regular female employees. The Korean Personnel Administration Journal. 19, 301-321.

Chang, K., Chelladurai, P. (2003). Comparison of part time and full time workers: Commitment and citizenship behaviors in Korean sports organizations. Journal of Sports Management, 17, 394-416.

Chester, Barnard, I. (1962). The Functions of the Executive. Cambridge Mass: Harvard University Press.

Ching, P., Chen, Chiung, W., Yi, H. C., Lee. (2008). The study of relationship among supervisor transformational leadership, organizational citizenship behaviour and turnover intention in R\&D personnel of communication related industry. Proceedings of the 17th International Conference on Management of Technology-IAMOT2008, April 6-10, Dubai, UAE. 
Costa, P. T., \& McCrae, R. R. (1989). NEO-PI Professional Manual. Odessa, FL: Psychological Assessment Resources.

Costa, P. T., \& McCrae, R. R. (1992). NEO PI-R Professional Manual. Odessa, FL: Psychological Assessment Resources.

Costa, P. T., McCrae, R. R. (1986). Major contributions to the psychology of personality. In: S.C. Modgil (Ed.): Hans Eysenck: Searching for a scientific basis for human behavior. Barcombe Lewes Sussex, England: Falmer: 63$72,86,87$.

Costa, P. T., McCrae, R. R. (1989). NEO-PI professional manual. Psychological Assessment Resources, Odessa. FL.

Deckop, J., Mangal, R., Circa, C. (1999). Getting More that You Pay For: Organizational Citizenship Behavior and Pay for Performance Plan. Academy of Management Journal. 42(4), 420-428.

Deluga, R. J. (1994). Supervision trust building, leader-member exchange and OCB. Journal of Occupational and Organizational Psychology, 67, 315326.

Diefendorff, J. M., Brown, D. J., Karmin, A. M., Lord, R. G. (2002). Examining the role of job involvement and work centrality in predicting organizational citizenship behaviour and job performance. Journal of Organizational Behaviour, 23, 93-108.

Dr. Bakshi, A., Kumar, K. (2009). Manual for Organizational Citizenship Behaviour Scale. Varanasi: Prasad Psycho Corporation.

Dr. Taj, H. (2001). Manual for Leadership Effectiveness Scale.

Dyne, V. L., Cummings, L. L., McLean, J. (1995). Extra role behaviors: In pursuit of construct and definitional clarity (a bridge over muddied waters). In Cummings, L. L., Van D. L., Graham, J., Dienesch, R. M. (1994). Organizational citizenship behavior: construct redefinition, measurement, and validation. Academy of Management Journal, 37, 765802.

Dysvik, A., Kuvaas, B. (2008). The relationship between perceived training opportunities, work motivation and employee outcomes. International Journal of Training and Development, 12 (2), 138-157.

Elanain, H. A. (2007). Relationship between Personality and Organizational Citizenship Behaviour: Does Personality Influence Employee Citizenship? International Review of Business Research Papers, 3(4), 31-43.

Erturk, A., Yilmaz, C., Ceylan, A. (2004). Promoting organizational citizenship behaviours: Relative effects of job satisfaction, organizational commitment and perceived managerial fairness. METU Studies in Development, 31, 189-210. 
Euwema, Martin, C., Wendt, H., Emmerik, H. V. (2007). Leadership styles and group organizational behaviour across cultures. Journal of Organizational Behaviour, 28(8), 1035-1057.

Feather, N. T., Rauter, K. A. (2004). Organizational citizenship behaviours in relation to job status, job insecurity, organizational commitment and identification, job satisfaction and work values. Journal of Occupational and Organizational Psychology, 77, 81-94.

Finkelstein, L. M., Farrell, S. K. (2007). An expanded view of age bias in the workplace. In Shultz K., Adams G. (Eds.) Aging and Work in the $21^{\text {st }}$ Century . Hillsdale, NJ: Lawrence Erlbaum, 73-108.

Funder, D. C., (2001). The Personality Puzzle (2nd ed.), Norton, New York.

Hoffman, B. J., Blair, C. A., Meriac, J. P., Woehr, D. J. (2007). Expanding the Criterion Domain? A Quantitative Review of the OCB Literature. Journal of Applied Psychology, 92, 555-566.

Hogan, J., Holland, B. (2003). Using theory to evaluate personality and job-performance relations: A socioanalytic perspective. Journal of Applied Psychology, 88, 100-112.

Hopkins, K. M. (2002). Organizational citizenship in social service agencies. Administration in Social Work, 26(2), 1-15.

Hough, L. M. (1992). The "Big Five" personality variables-construct confusion: Description versus prediction. Human Performance, 5, 139155.

Howard, P. J., Howard, J. M. (1995). The Big Five Quick start: An introduction to the Five-Factor Model of Personality for human resource professionals. Charlotte, NC: Centre for Applied Cognitive Studies.

Hurtz, G. M., Donovan, J. J. (2000). Personality and job performance: The Big Five revisited. Journal of Applied Psychology, 85 (6), 869-879.

Kidder, D.L. (1995). On call or answering a calling? Temporary nurses and extra role behaviors. Paper presented at the annual meeting of the Academy of Management, Vancouver.

King, E. B., George, J. M., Hebl. (2005). Linking Personality to Helping Behaviors at Work: An Interactional Perspective. Journal of Personality 73(3).

Konovsky, M. A., Organ, D. W. (1996). Dispositional and contextual determinants of organizational citizenship behaviour. Journal of Organizational Behaviour, 17, 253-266.

Kumar, K., Bakhshi, A., Rani, E., (2009). Linking the Big Five Personality Domains to Organizational Citizenship Behaviour. International Journal of Psychological Studies, 1(2). 
McCrae, R. R., John, O. P. (1992). An introduction to the five-factor model and its applications. Journal of Personality, 2, 175-215.

Organ D. W. \& Konovsky, M. (1989). Cognitive versus affective determinants of organizational citizenship behaviours. Journal of Applied Psychology, 74, 157-164.

Organ, D. W. (1988). Organizational citizenship behavior: The good soldier syndrome. MA: Lexington Books.

Organ, D. W. (2002). Personality and organizational citizenship behaviour. Journal of Management, Indiana University, USA, Volume 20, Issue 2.

Organ, D. W., (1990). The motivational basis of organizational citizenship behavior. Research in Organizational Behavioral, 43-72.

Organ, D. W., Podsakoff, P. M., MacKenzie, S. B. (2006). Organizational Citizenship Behavior: Its Nature, Antecedents and Consequences. Beverly Hills, CA: Sage.

Organ, D. W., Ryan, K. (1995). A meta-analytic review of attitudinal and dispositional predictors of organizational citizenship behavior. Personnel Psychology, 48, 775-800.

Pearce, J. L. (1993). Toward an organizational behaviour of contract labourers: Their psychological involvement and effects on Saadia Tayyab employees' co workers. Journal of Management, 36, 1082-1096.

Pfiffner, J. P. (2002). Judging Presidential Character. Public Integrity, 5:724.

Phares, J. E. (1991). Introduction to Personality (3rd ed.). New York: Harper Collins.

Podsakoff, P. M., \& Organ, D. W. (1986). Self-reports in organizational research: Problems and prospects. Journal of Management, 12, 531-544.

Podsakoff, P. M., Ahearne, M., MacKenzie, S. B. (1997). Organisational citizenship behaviour and the quantity and quality of work group performance. Journal of Applied Psychology, 82(2), 262-270.

Podsakoff, P. M., MacKenzie, S. B. (1994). Organisational citizenship behaviour and sales unit effectiveness. Journal of Marketing Research, 31, 351-363.

Podsakoff, P. M., MacKenzie, S. B., Moorman, R. H., Fetter, R. (2002). Transformational leader behaviours and their effects on followers' trust in leader, satisfaction, and organizational citizenship behaviours. The Leadership Quarterly, 1(2).

Podsakoff, P. M., MacKenzie, S., Pain, B., Bachrach, D. (2000). Organisational citizenship behaviour: A critical review of the theoretical and empirical literature and suggestions for future research. Journal of | Management, 26(3), 513-563. 
Podsakoff, P., MacKenzie, M., Scott, B., Bommer, William, H. (1996). Transformational leader behaviors and substitutes for leadership as determinants of employee satisfaction, commitment, trust, and organizational citizenship behaviors. Journal of Management, 22(2), 259298.

Posdakoff, P., MacKenzie, S., Paine, B., Bachrach, D. (2000). Organizational citizenship behavior: A critical review of the theoretical and empirical literature and suggestions for future research. Journal of Management, 26(3), 513-563.

Punj, A., Venkat R. K. (2006). Transformational leadership and altruism: Role of power distance in a high power distance culture. Conference Paper in Proceedings: Proceedings of the annual conference of the Administrative Sciences Association of Canada.

Ryckman, R. (1982). Theories of personality. (2nd/ ed.) Monterey, CA: Brooks/Cole.

Sager, J. K. (1994). A structural model depicting salespeople's job stress. Journal of the Academy of Marketing Science, 22, 74-84.

Singh, A. K., Singh, A. P. (2009). Does Personality Predict Organisational Citizenship Behaviour among Managerial Personnel. Journal of the Indian Academy of Applied Psychology, 35(2).

Van D. L., Ang, S. (1998). Organizational citizenship behaviour of contingent workers in Singapore. Academy of Management Journal, 41, 692-703. 